\title{
Effects of internal erosion on mechanical properties evaluated by triaxial compression tests
}

\author{
M. Sato ${ }^{\text {i) }}$ and R. Kuwano ${ }^{\text {ii) }}$
}

i) Researcher, School of Agriculture, Kyoto University, Oiwakecho, Kitashirakawa, Sakyo-ku, Kyoto 606-8502, Japan. ii) Professor, Institute of Industrial Science, the University of Tokyo, IIS, 4-6-1, Komaba, Meguro-ku, Tokyo 153-8505, Japan.

\begin{abstract}
The aim of this research is to reveal the influence of internal erosion on mechanical properties by laboratory testing. Internal erosion is the transportation of fine particles with seepage flows inside the ground. A large degree of erosion induces various ground disasters, such as landslides and sinkholes. However, the influence of a small degree of internal erosion has not been examined. This is probably because the erosion progresses slowly, due to the repetition of seepage flows in the ground over a long period, without any obvious collapse or deformation. A new triaxial testing apparatus was developed in this study, that allows for a subtle amount of internal erosion inside the specimen. A field soil, containing around $10 \%$ clay, was used. Following the internal erosion, due to downward seepage, the specimen was monotinically sheared under a drained condition. LDTs and clip gages were mounted onto the specimen and the deformation characteristics were obtained during both erosion and monotonic shearing.
\end{abstract}

Keywords: seepage, internal erosion, triaxial test, internal instability

\section{INTRODUCTION}

Internal erosion is the migration of the finer fractions through the courser fractions of a soil with seepage flows ${ }^{1)}$. Recent studies have mainly focused on the large degree of erosion following levee and dam failures ${ }^{2), 3)}$. However, the influence of a small degree of internal erosion on the ground has not yet been revealed. This research developed a confining compression test apparatus allowing an invisible, limited degree of internal erosion inside the specimen, subjected to a downward seepage flow, to obtain the variation in mechanical properties of the soil inducing the erosion.

\section{TEST APPARATUS AND PROCEDURE}

Figure 1 depicts the schematic figure of the improved triaxial test apparatus used to induce internal erosion inside a specimen. 52 holes, $5 \mathrm{~mm}$ in diameter, are placed in the top and bottom plates, allowing for the discharge of soil. The top cap and the bottom pedestal perform soil retrieving, and are connected to the upper and lower water tanks, respectively. A tube, $8 \mathrm{~mm}$ in diameter, is applied to obtain the smooth progression of soil discharge and infiltration. The change in weight of the water tanks is monitored by a load cell placed above each water tank during the experiment.

The specimen is $75 \mathrm{~mm}$ in diameter and $160 \mathrm{~mm}$ in height; three CGs (clip gages) and four LDTs (linear displacement transducers) are mounted on the specimen, as illustrated in Figure 2. The CGs and LDTs are capable of measuring the displacement in the horizontal and vertical directions of the specimen, respectively. An EDT (external displacement transducer) is placed on the outside of the cell to measure the vertical displacement of the specimen. The EDT has a longer measurable range than the LDT. Atmospheric pressure is released on the specimen, and confining pressure is controlled only by the cell pressure monitored from the HCDPT (high-capacity differential pressure transducer) during the tests.

The test procedure is run as follows. First, the specimen is compacted with the approximately optimal water content into sixteen layers of equal thickness. Following the specimen preparation, $25 \mathrm{kPa}$ of isotropic confining pressure is imposed on the specimen and maintained until the end of the test. The bottom pedestal is subsequently connected to the lower tank filled with water, which gradually infiltrates into the specimen. After one day of infiltration, the upper water tank is filled with water and the vacant lower water tank is attached to the top cap and the bottom pedestal, respectively. The upper tank is released to atmospheric pressure, and $75 \mathrm{kPa}$ of negative pressure is applied to the lower tank, which generates a downward seepage flow. The discharged water and soil are finally collected in the lower tank. After the downward seepage is terminated, the lower water tank is almost completely occupied with water (approximately $1.5 \mathrm{~L}$ ), and the specimen is monotonically sheared with $0.055 \% / \mathrm{min}$ under a drained condition. During the test, 
cyclic loading is applied three times: i) before infiltration from the lower tank, ii) after infiltration and iii) after downward seepage, to verify the variation in soil stiffness. Eleven cycles with the amplitude of $0.002 \% /$ strain are imposed at each loading step.

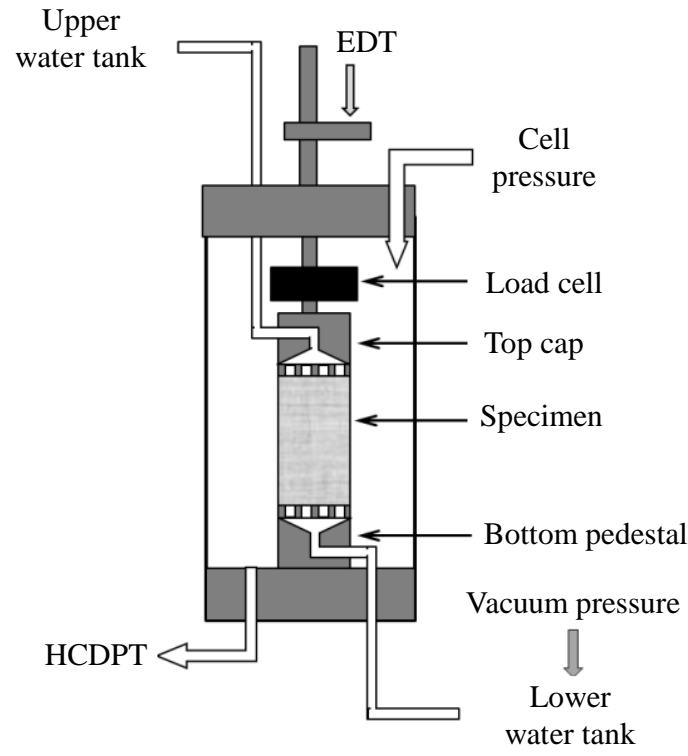

Fig. 1. Drawing of the testing apparatus.

\section{TEST MATERIALS AND CONDITIONS}

Table 1 lists the test conditions. Edosaki sand $\left(G_{s}=\right.$ $2.705 \mathrm{~g} / \mathrm{cm}^{3}, \rho_{d \max }=1.76 \mathrm{~g} / \mathrm{cm}^{3}, w_{\text {opt }}=14.2 \%, e_{\min }=$ 0.868 , and $e_{\max }=1.383$ ) is used in the series of tests and contains about $20 \%$ fines. The particle size distribution of this sand is shown in Figure 2. Edosaki sand is regarded as unstable material whose coarser fractions are unable to prevent the transportation of its finer fractions, according to Kenny et al. (1985) ${ }^{4)}$. The variables examined in the test series are the amounts of discharged soil and charged water. The former is controlled by the filter properties (material and pore size) on the bottom plate, while the latter is controlled by both the filter properties and the amount of penetrated water. Two kinds of materials are adopted for the filter, paper and cloth, and four pore sizes are used, micro pore (supposed to be under $5 \mu \mathrm{m}$ ), 0.05 $\mathrm{mm}, 1 \mathrm{~mm}$ and $5 \mathrm{~mm}$. The $5 \mathrm{~mm}$ size contains only two holes created on the filter paper of micro pore size. Three amounts of penetrated water are given: approximately $1.5 \mathrm{~L}, 3.0 \mathrm{~L}$ and $6.0 \mathrm{~L}$. The pore size and the amount of penetrated water are proportional to the degree of internal erosion. The erosion rate (\%) is the ratio of the weight of the discharged soil to the weight of the entire specimen. The compaction degree is relatively identical in all cases, as shown in Table 1 , and corrected by taking account of the deformation after the downward seepage flow. The test series is separated into two groups: 1) without erosion and 2) with erosion. Without erosion represents the test cases that prevent soil discharge, using the filter with a micro pore size, and with erosion includes all the test cases, except for those without erosion.

Table 1 Test conditions.

\begin{tabular}{|c|c|c|c|c|c|}
\hline \multirow[t]{2}{*}{$\begin{array}{l}\text { Test } \\
\text { code }\end{array}$} & \multirow[t]{2}{*}{$\begin{array}{l}\text { Material } \\
\text { of the } \\
\text { filter }\end{array}$} & \multirow[t]{2}{*}{$\begin{array}{l}\text { Pore size } \\
\text { of the } \\
\text { filter }\end{array}$} & \multirow{2}{*}{$\begin{array}{l}\begin{array}{l}\text { Inflow } \\
\text { water }\end{array} \\
\mathrm{L}\end{array}$} & \multirow{2}{*}{$\begin{array}{l}\text { Dc } \\
\%\end{array}$} & \multirow{2}{*}{$\begin{array}{l}\text { Erosion } \\
\text { rate }\end{array}$} \\
\hline & & & & & \\
\hline pm-1* & paper & micro & 1.31 & 87.2 & 0 \\
\hline pm- $2 *$ & paper & micro & 1.21 & 86.5 & 0 \\
\hline $\mathrm{cm}-1 *$ & cloth & micro & 1.19 & 86.7 & 0.03 \\
\hline $\mathrm{cm}-2 *$ & cloth & micro & 1.24 & 86.4 & 0 \\
\hline $\mathrm{c} 0.05$ & cloth & $0.05 \mathrm{~mm}$ & 1.46 & 87.1 & 0.06 \\
\hline c1-1 & cloth & $1 \mathrm{~mm}$ & 1.49 & 88 & 0.18 \\
\hline $\mathrm{c} 1-2$ & cloth & $1 \mathrm{~mm}$ & 1.37 & 85 & 0.21 \\
\hline c1-twice & cloth & $1 \mathrm{~mm}$ & 2.68 & 87.2 & 0.4 \\
\hline $\begin{array}{l}\text { c1-4time } \\
\mathrm{s}\end{array}$ & cloth & $1 \mathrm{~mm}$ & $\approx 6.00$ & 86.6 & 0.61 \\
\hline p5-1 & paper & $\begin{array}{l}5 \mathrm{~mm} \\
(2 \text { holes })\end{array}$ & 1.29 & 87.5 & 0.993 \\
\hline $\mathrm{p} 5-2$ & paper & $\begin{array}{l}5 \mathrm{~mm} \\
\text { (2 holes) }\end{array}$ & 1.26 & 86.3 & 0.873 \\
\hline
\end{tabular}

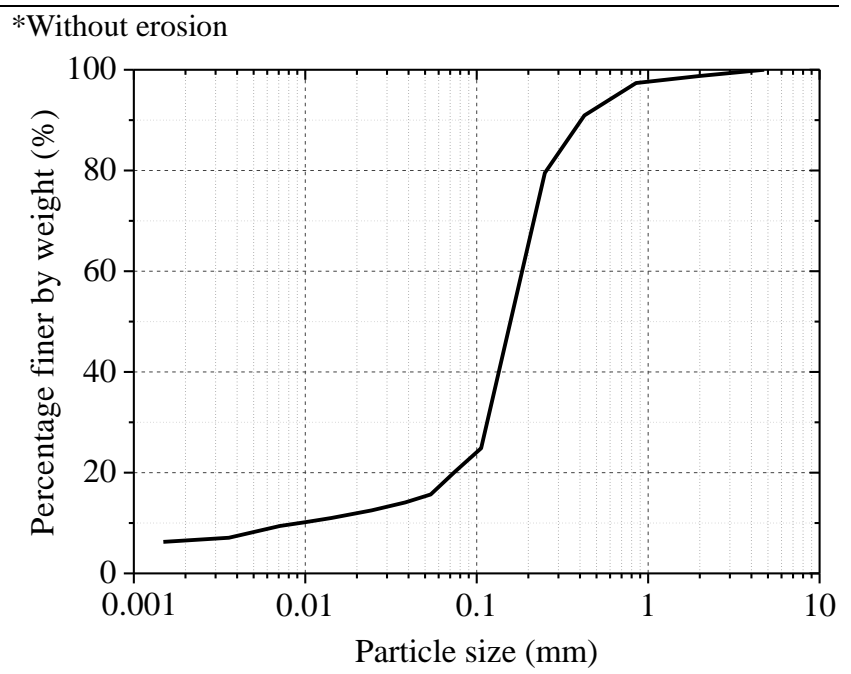

Fig. 2. Particle size distribution of Edosaki sand.

\section{TEST RESULTS}

\subsection{Young's modulus and Poisson's ratio}

The variations in Young's modulus and Poisson's ratio are shown in Figure 3. Young's modulus was obtained from the measurement of the LDTs and the load cell at cyclic loadings, while Poisson's ratio was obtained from the CGs and LDTs. The variation in Young's modulus was derived from the division of the present Young's modulus by the Young's modulus before water infiltration. As seen in Figure 3(a), water infiltration induced the decrease in Young's modulus as a result of the increase in water content in the specimen. A trend in Young's modulus, in the cases with erosion, is that it decreased more significantly after downward seepage than in the cases without erosion, although the extent of the decline in Young's modulus did not correlate directly to the erosion rate. Incidentally, the 
change in void ratio due to internal erosion was negligible (under $0.5 \%$ ) for stiffness, and there was no obvious difference between the Young's modulus of the upper portion (calculated from LDT1 \& LDT3) and that of the lower portion (from LDT2 \& LDT4). The values for Poisson's ratio were scattered. (See Figure 3(b))

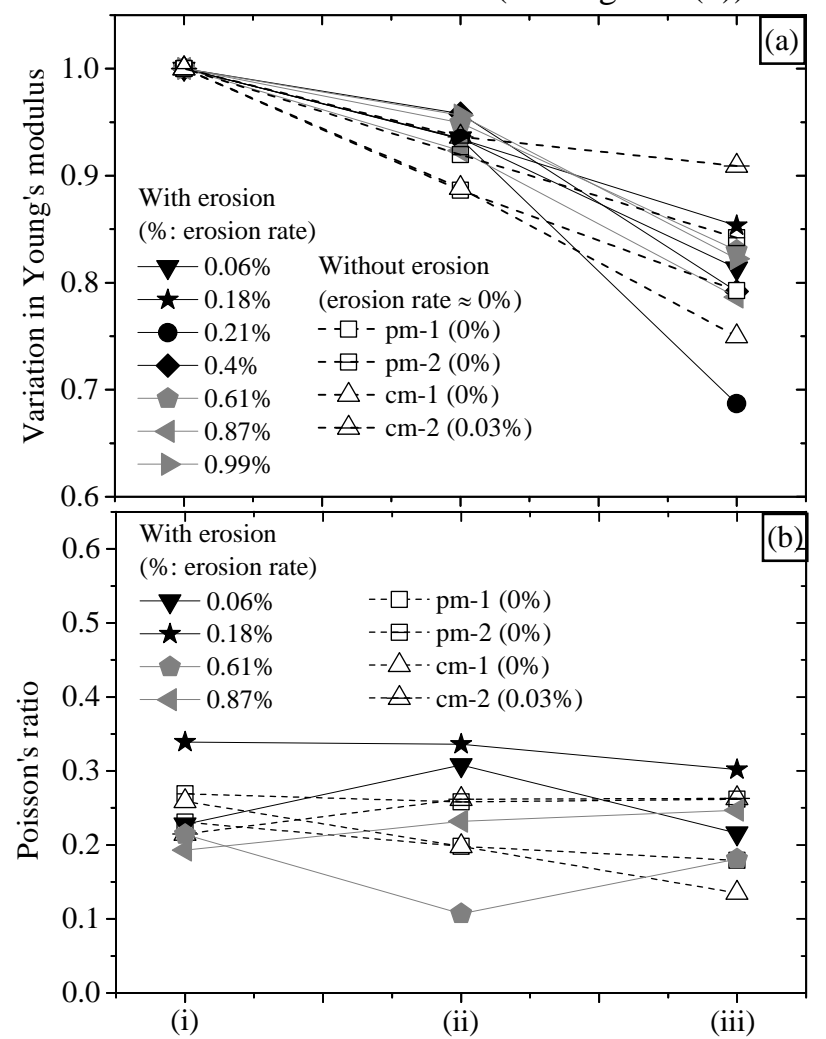

*(i) Before infiltration, (ii) After infiltration and (iii) After downward seepage

Fig. 3. a) Variation in Young's modulus and b) Poisson's ratio.

\subsection{Deformation due to internal erosion}

Figures 4(a), (b) and (c) show the changes in axial strain $\left(\varepsilon_{a}\right)$, horizontal strain $\left(\varepsilon_{h}\right)$ and volumetric strain $\left(\varepsilon_{v}\right)$ due to the downward seepage versus erosion rate, respectively. Note that not only the test series with higher densities $\left(D_{c} \approx 87 \%\right)$, but also those with lower densities $\left(D_{c} \approx 82 \%\right)$, are plotted in the figures. They are not listed in Table 1, because the variation in strain did not depend on the specimen's density, but on its erosion rate. Average $\varepsilon_{a}$ and $\varepsilon_{h}$ were calculated from all LDTs and CGs, respectively. Furthermore, the upper $\varepsilon_{a}$ was from the average of LDT1 and LDT3, while the lower one was from that of LDT2 and LDT4. The upper, center and lower $\varepsilon_{h}$ were from CG1, CG2 and CG3, respectively. Each portion of $\varepsilon_{v}$ was subsequently estimated from the axial and horizontal strains of the corresponding portion of the specimen.

A comparison between the axial and horizontal strains shows that the axial strain was smaller than the horizontal strain. The strain was not uniform for the entire specimen along the seepage flow; the upper $\varepsilon_{a}$ slightly decreased with an increase in the erosion rate, opposite from the lower one. Moreover, the rise in lower $\varepsilon_{h}$ correlated linearly with that of the erosion rate, whereas the upper one was relatively constant with the progression of erosion. The behavior of the volumetric strain was similar to that of the lateral strain. The average $\varepsilon_{v}$ increased and was approximately equivalent to half the erosion rate, suggesting that the internal erosion caused the void ratio to increase. In contrast, the lower portion contracted over the erosion rate.
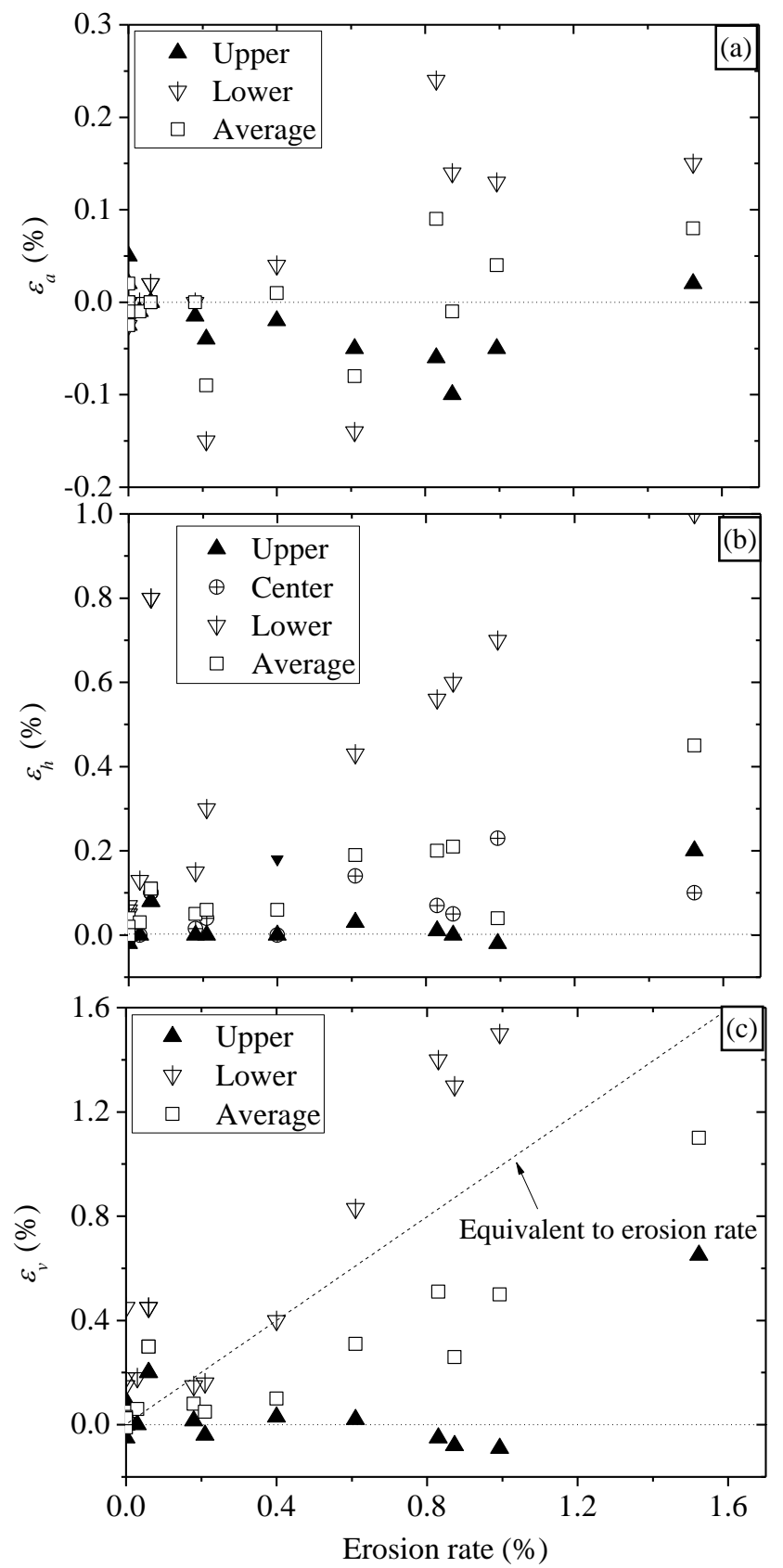

Fig. 4. (a) axial strain, (b) horizontal strain and (c) vertical strain.

\subsection{Monotonic shearing}

The relevance of the secant stiffness $\left(E_{s}\right)$ and the erosion rate at axial strain $\varepsilon_{a}=1.0 \%$ and $5.0 \%$, is shown in Figure 5. The axial strain was measured by the EDT, for the measurable range in LDT was not adequate. Comparing the scant stiffness at $\varepsilon_{a}=1.0 \%$ 
and $5.0 \%$ shows the descent of the scant stiffness with the ascent of the erosion rate, disappearing with an increase in $\varepsilon_{\mathrm{a}}$. The influence of the invisible skeleton deformation, due to internal erosion, was reduced by the progression of deformation with shearing. The hypothesis that the residual stress was relatively similar in all cases was proved (Sato et al., 2014 ${ }^{5)}$ ).

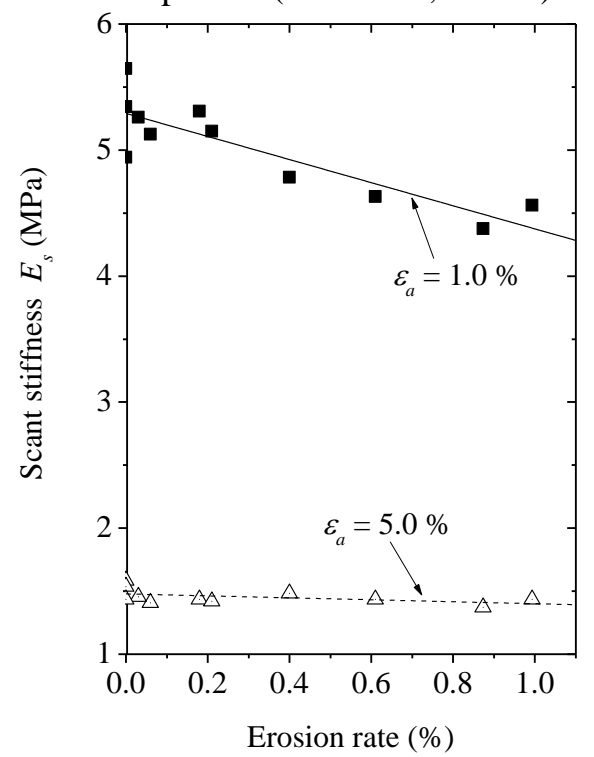

Fig. 5. Scant stiffness at $\varepsilon_{a}=1.0 \%$ and $5.0 \%$.

\subsection{Dilatancy}

Figure 6 shows $\varepsilon_{a}$ and $\varepsilon_{v}$ during monotonic shearing. The volmetric strain was measured by LDTs and CGs, whose test series was larger with erosion than without it. Thus, erosion made the specimen more contractive.

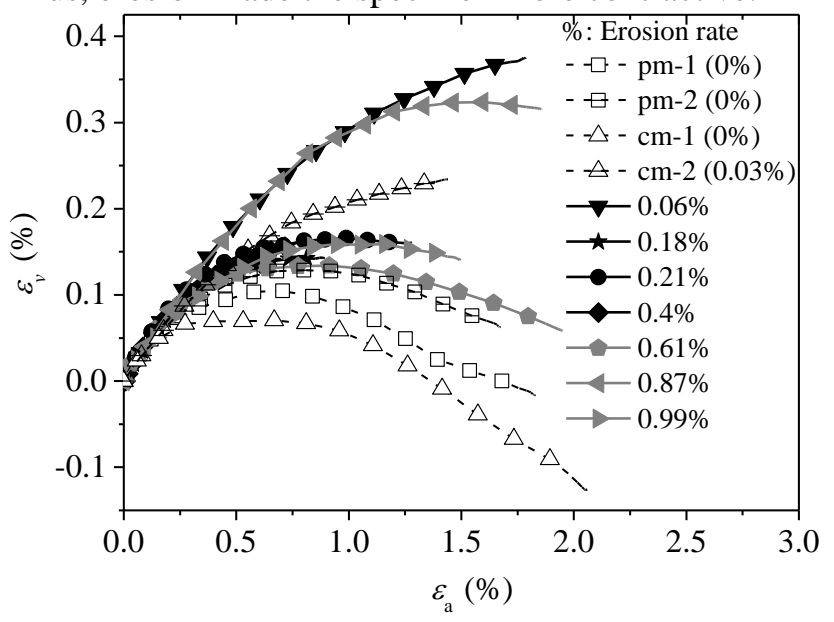

Fig. 6. Strain development during shearing.

\section{IMPLICATIONS AND CONCLUSIONS}

This research has described tests performed with a newly developed triaxial testing device that allows for internal erosion inside the specimen. A small degree of internal erosion (erosion rate $\geq 1.0 \%$ ) caused a decrease in soil stiffness, especially in the vertical direction, similar to the seepage flow. The lower portion of the specimen contracted proportionally with the erosion rate, although the upper portion was not significantlly deformed due to the internal erosion. It was evident that erosion was not uniform along the specimen; a large amount of soil was eroded from the lower portion, according to Kondo et al. (2013) ${ }^{6}$.

A small degree of erosion did not evidently affect either the peak or the residual stress during shearing. On the other hand, scant stiffness decreased with a rise in the erosion rate in the strain ranging from small $(0.002 \%)$ to intermediate $(>5.0 \%)$; this was attributed to the subtle skeleton deformation. An approximately $20 \%$ decrease in scant stiffness with a $1 \%$ erosion rate was obtained at $\varepsilon_{\mathrm{a}}=1.0 \%$. The descent of the soil stiffness, by internal erosion, faded due to the progress of shearing, since the influence of deformation with shearing exceeded that of the skeleton deformation with erosion. The skeleton deformation was also predicted from the contractive behavior of the soil inducing internal erosion, and an additional numerical analysis indicated similar trends ${ }^{7), 8)}$ Consequently, it was found that the deterioration of in situ ground structures probably occurs due to continuous seepage flows over a long period, particularly along localized seepage.

\section{ACKNOWLEDGEMENTS}

This research was financially supported by Grant-in-Aid for JSPS Fellows (No. 11J08637). Edosaki sand was provided by the Public Works Research Institute (PWRI).

\section{REFERENCES}

1) Haghighi, I., Chevalier, C., Duc, M. and Guédon, S. (2013): Improvement of hole erosion test and results on reference soils, Journal of Geotechnical and Geoenvironmental Engineering, Vol. 139, No. 2, 330-339. DOI: 10.1061/(ASCE)GT.1943-5606.0000747

2) Wood, D.M. (2007): The magic of sands-The 20th Bjerrum Lecture presented in Oslo, 25 November 2005, Canadian Geotechnical Journal, Vol. 44, 1329-1350. DOI: 10.1139/T10-071

3) Stewart, R.A. and Watts, B.D. (2000): The W.A.C. Bennet Dam sinkhole incident., Proceedings of the 53rd Canadian Geotechnical Conference, Montreal, Canada. Vol. 1, 39-45.

4) Kenny,T.C. and Lau.D. (1985): Internal Stability of granular filters. Canadian Geotechnical Journal, Vol. 22, 215-225. DOI: 10.1139/T86-068

5) Sato, M. and Kuwano, R. (2014): Effects of internal erosion on deformation characteristics in the triaxial compression test, Proceedings of 7th International Conference of Scour and Erosion, Perth, Australia, 233-239.

6) Kondo, A., Maeda, K., and Yamada, T. (2013): Stability of fine particle erosion based on grading shape and void structures, Proceedings of the 5th Comprehensive Symposium on Methane Hydrate, Tokyo, Japan, 28-35.

7) Hicher,P.-Y. (2013): Modelling the impact of particle removal on granular material behaviour, Géotechnique, Vol. 63, No. 2, 118-128. DOI: 10.1680/geot.11.P.020

8) Maeda, K., Wood, D.M. and Kondo, A. (2012): Micro and macro modeling of internal erosion and scouring with fine particle dynamics, Proceedings of 6th International Conference on Scour and Erosion, Paris, France, 321-328. 